\title{
The Locus and Focus of Public Administration Research in Tanzania: An Assessment of the Journal of Public Sector Management, 2011-2016
}

\author{
Ramadhani Marijani \\ Tanzania Public Service College, Tabora, Tanzania
}

\begin{abstract}
This paper presents the locus and focus of public administration research in Tanzania through an assessment of articles published in the Journal of Public Sector Management (JPSM) from 2011 to 2016. A content analysis of 31 articles, guided by the research topic variable and comparative analysis of the categories of unit standards for public administration and management and the "Practices for Effective Local Government" developed by the International City/County Management Association (ICMA) was invoked. The findings indicate the heavy slant (96.62\%) towards practice-oriented research at the expense of theory development. Apart from providing reasons for this slant, it is recommended in this paper that editors and authors of JPSM should include topics and themes that focus on theory and research so as to restore the erstwhile glory of public administration intellectual predominance and its foundations.
\end{abstract}

Keywords: public administration, research, theory, public sector

In recent years, Tanzanians' scientist spurting in the field of scientific publication is recommendable. The use of publications in academic promotions and appointments as criterion has brought about an avalanche of publications (Unal, Metin, \& Veysel, 2012, p. 1) and academia has become an environment where researchers are succumbed into publish-or-perish entrepreneurs, to the extent of foregoing the clarion call of higher ideals of the pursuit of knowledge (Rekdal, 2014, p. 638). If this trend is left unabated, it will create a fertile environment for conception of "academic corner-cutting pregnancies" which will give birth to the "academic urban legends" who are in the dire need for academic positions and therefore to them number of publications is more important than the rigor (Rekdal, 2014, p. 638).

It is in the above context that Wessels $(2005$, p. 1499) reminded us of the urge to establish the practical usefulness of public administration discipline to the public sector. This is because the public sector is a key component of the economy, and it plays a critical role in economic growth and development in a country (Fourie \& Wayne, 2017, p. 170). Therefore, in order to deliver better services, governments need to meet many challenges, both simple and complex; as a result, new problems arise and it is difficult for public officials to solve them alone. Public administration researchers must therefore offer a helping hand by producing the knowledge that will solve these complex public sector problems without jeopardizing its ability to survive as an academic discipline and scholarly community (Van der Waldt, 2013, p. 49; Wessels, 2005, p. 1500).

Corresponding author: Ramadhani Marijani, Ph.D., Tanzania Public Service College, Tabora, Tanzania; research fields: public administration research, local governance, decentralization. 
This paper is therefore an attempt to assess the focus and locus of the public administration research in Tanzania. This objective is achieved by reviewing the articles published in the Tanzania Public Service College Journal of Public Sector Management (JPSM) from 2011 to 2016. To achieve that, analysis is also done on: (1) the categories of unit standard for public administration and management; and (2) the practice for effective local government development by the International City/County Management Association (ICMA).

The remainder of the paper is structured as follows: The nature of scientific inquiry is presented to situate the locus and focus of public administration research; thereafter, the state of research in public administration in international and African perspectives is presented; next, the focus and locus of public administration research in Tanzania is explored. Followed by, the methodology is used. The paper concludes by suggesting possible interventions to improve public administration research in Tanzania.

\section{The Nature of Scientific Inquiry in Public Administration and Management}

Social scientists, as opposed to the natural and health scientists, conduct research in order to seek answers and understand the social world (Auriacombe \& Holtzhausen, 2014, p. 11). The social world entails sound beings, institutions and organizations, actions and events, interventions, as well as cultural products (Auriacombe \& Holtzhausen, 2014, p. 11). The nature of scientific inquiry in public administration is a subject of contested debate, a discourse that Greenwood and Eggins (1995) christened "shifting sands", Kettl (2000) baptized a "revolution", and Ospina and Dodge (2005) conceived as a "narrative turn". These "shifting sands", "revolution", and "narrative turn" started with Woodrow Wilson's (1887) "The Study of Administration", to Leonard D. White's (1926) Introduction to the Study of Public Administration, followed by the contributions of Frederick W. Taylor's (1911) Principles of Scientific Management, Gulick and Urwick's (1937) "Notes on the Theory of Organization" to the paradigmatic debate by Henry (1975).

Such a diverse scope of inquiry poses a potential epistemological and methodological flaw which may hinder development of the field (Van der Waldt, 2013, p. 49). In this regard, qualitative research methods should be preferred in studying people's perceptions and opinions as well as social phenomena (Auriacombe \& Mouton, 2007, p. 442). This study subscribes to this view and employs qualitative method.

\section{The State of Research in Public Administration}

There is plethora of international and local studies on the general state of research in the academic field of public administration. In this section, the key studies in this regard will be briefly highlighted to establish an understanding of the state of research in two perspectives in which one is international and the other is local.

\section{International Studies on the State of Public Administration Research}

Numerous international studies, chiefly American studies, assessing the state of the research have included the work by Box (1992), Hummel (1991), White (1986), White and Adams (1994), Houston and Delevan (1990), Perry and Kraemer (1986), and Stallings and Ferris (1988). These works have all come to the conclusion regarding the poor state of research in the field of public administration. There are also records in the British side which featured Greenwood and Eggins (1995) and Elcock (2004). Similarly in Russia, Sanina, Balashov, and Kaysarova (2016) examined the state of research in the field from 2010 to 2014. Likewise in China, Wu, He, and Sun, (2013) studied the state of research in discipline from 1998 to 2008 from a sample of 2,877 articles. The above studies have also come to the same conclusion that research in the public administration is in a weak state (Milne, 2009, p. 30). 


\section{The African Studies on the State of Public Administration Research}

There is the dearth of empirical literature on the state of public administration research in Africa as compared to the United States, Europe, and Asia (Mabin, 2003; Cameron \& McLaverty, 2008; Wessels, 2008; Marijani, 2017). The available works include studies by Brynard (1989), Hubbell (1992), Clapper (2000), Wessels (2004), Cameron and McLaverty (2008), and Marijani (2017). These studies on the state of journals also concluded that research in public administration was in a poor state.

Historically, it was common practice to find journal publications to be dominated by articles focusing mainly on the practice of public administration (Milne, 2009, p. 35). For instance, Thornhill (2008, p. 13) assessed articles published on the Journal of Public Administration from 1970 to 1980 and concluded that nearly 70 articles were practice-oriented and only 10 articles were oriented to the science or field of public administration (Milne, 2009, p. 35).

Hubbell's (1992) qualitative content assessment of 83 articles in the Journal of Public Administration from 1986 to 1990 concluded that most of the articles fell within functionalist perspectives and lacked critical analysis and could be classified as following administrative process approach (Hubbell, 1992, p. 13; Milne, 2009, p. 35).

Clapper's (2000) examination of South African public administration and public management publications further concluded that there was limited content on the theory of practice and generally there was poor state of research in the publications. The work of Wessels (2004) studied on the articles published in the Journal of Public Administration from 2000 to 2004 and pointed to the need for generating appropriate knowledge in the public administration.

Equally, Cameron and McLaverty (2008) conducted an analysis of Journal of Public Administration and Administratio Publica from 1994 to 2006 to establish the state of academic research in the field. They also concluded that there has been little theory development in the field as revealed by over $85 \%$ of the articles. The study also revealed little originality as indicated by $67.4 \%$ of the journal articles which were the result of the desk research (Milne, 2009, p. 38).

In Tanzania, Marijani (2017) conducted qualitative content analysis of the articles published in the Journal of Policy and Leadership (JOPL) and Uongozi: Journal of Management and Development from 2007 to 2014 and concluded that there has been very little theory development in the public administration research in Tanzania. From the foregoing analysis, it appears that there are substantial concerns regarding the quality of research in public administration discipline both internationally and in Africa.

\section{Focus and Locus of Public Administration Research in Tanzania}

The focus and locus of public administration research in Tanzania can be found in the dissertations, theses, published research reports, and articles in the peer-reviewed journals. For the purpose of this paper, it has been opted to assess the articles published in the Journal of Public Sector Management (JPSM) now in its fourth volume. This choice is motivated by the fact that JPSM is the journal dedicated to public sector management in Tanzania.

The JPSM is a biannual peer-reviewed journal published by Tanzania Public Service College (TPSC). The journal covers the areas of public finance and accounting, public administration, local government administration, organizational development, human resource management, and other areas related to public sector management. 
How does one determine the locus and focus of public administration research? There are numerous ways; and the most popular one is to borrow the erstwhile criteria used by McCurdy and Cleary (1984, p. 49) on the state of research at the doctoral level which included a criterion of purpose.

(1) Whether the research was more oriented towards theory building or needs of practices?

(2) Was the research topic central to public administration discipline?

However, there are a lot of contextual issues surrounding the usefulness of the above criteria; one is the lack of uniformity of the locus and focus of public administration research between the point of origin of the criteria which is the United States and African context (Wessels, 2005, p. 1504).

\section{Methodology}

\section{Data Collection}

Data for this study were collected through a content analysis of the articles published in the JPSM in the period of 2011 to 2016. Content analysis reduces and simplifies data collection and produces results that may be measured qualitatively (Langos, 2014). Further, content analysis enables the researcher to structure qualitative data to achieve research objectives (Marijani, 2017, p. 83).

In this study, a database of 37 articles published in the JPSM in the period of 2011 to 2016 was compiled and used for analysis. The researcher is aware of the reliability of the following variables in the examination of the articles contribution to the public administration research: research topic; research purpose; research methodology; research focus; and institutional funding as they have been widely used (see McCurdy \& Cleary, 1984; White \& Adams, 1994; Perry \& Kraemer, 1986; Hubbell, 1992; Box, 1992; Wessels, 2004; 2005; Cameron and McLaverty, 2008; Wu et al., 2013; Sanina et al., 2016; Marijani, 2017).

However, for the purpose of the study, only research topic was used from mentioned variables. This is because a research topic should be applied first to establish whether an article contributes to theory development (Perry \& Kraemer, 1986). To control the problem of mutual exclusiveness of this variable, the articles were placed on their primary niche during coding process (Cameron \& McLaverty, 2008, pp. 82-90).

For the purpose of this paper and in order to be safe, Wessels' (2005, p. 1504) suggestions were followed and invoked the proposed unit standards for public administration and management (SGB) in the Table 1 next (Wessels, 2005, p. 1504).

Table 1

Categories of Unit Standards for Public Administration and Management

\begin{tabular}{|l|l|}
\hline 1. & Policy Analysis \& Management (POL) \\
\hline 2. & Development Management (DEV) \\
\hline 3. & Public Organizational Development \& Management (ODM) \\
\hline 4. & Managing Public Service Delivery (PSD) \\
\hline 5. & Human Resource Management (HRM) \\
\hline 6. & Financial Management \& Procurement (FMP) \\
\hline 7. & Information, Knowledge, Communication \& Technology Management (ICT) \\
\hline 8. & Public Management Ethics (ETH) \\
\hline 9. & Public Administration and Management History, Theory and Research (HTR) \\
\hline 10. & Disaster Studies (DIS) \\
\hline 11. & Inter-Governmental Relations (IGR) \\
\hline
\end{tabular}

Note. Source: Standard Generating Body (2005). 
This categorization reveals the following focus (see Table 2) of the research issues or topics reported in the Journal of Public Sector Management (JPSM) from 2011 to 2016.

Table 2

The Focus of Research Issues Reported in the Journal of Public Sector Management (JPSM) in the Period of 2011-2016

\begin{tabular}{llll}
\hline Categories & & Number & Percent (\%) \\
\hline 1 & Policy Analysis \& Management (POL) & 0 & 0 \\
2 & Development Management (DEV) & 0 & 0 \\
3 & Public Organizational Development \& Management (ODM) & 3 & 9.6 \\
4 & Managing Public Service Delivery (PSD) & 15 & 48.4 \\
5 & Human Resource Management (HRM) & 4 & 12.9 \\
6 & Financial Management \& Procurement (FMP) & 4 & 12.9 \\
7 & Information, Knowledge, Communication \& Technology Management (ICT) & 1 & 3.22 \\
8 & Public Management Ethics (ETH) & 1 & 3.22 \\
9 & Public Administration and Management History, Theory and Research (HTR) & 0 & 0 \\
10 & Disaster Studies (DIS) & 0 & 0 \\
11 & Inter-Governmental Relations (IGR) & 3 & 9.6 \\
\hline
\end{tabular}

Note. Source: JPSM (2011-2016).

The above categorization revealed the core issues of researchers contributing to the Journal of Public Sector Management. Table 2 indicates that $93.4 \%$ of the articles focused on five issues most common in public administration research: the management of public service delivery (48.4\%), human resource management $(12.9 \%)$, financial management and procurement in the public service $(12.9 \%)$, public organizational development and management (9.6\%), and inter-governmental relations studies $(9.6 \%)$. The findings indicate very little focus on public management ethics (3.22\%) and information, communication, and knowledge management in the public sector (3.22\%). Yet, the two areas are very crucial for service delivery in the public service.

Across the board, the articles do not contain any contribution on policy analysis and management, development management, public administration history, theory and research, and disaster studies, signaling prima facie biasness to practice-oriented than theory development of the discipline. This collaborates what Wessels (2005) reported that public administration is indeed an applied interdisciplinary field.

Understanding public administration as an academic discipline requires an appreciation of public administration as a practice as well (Cox, Gerald, \& Levin, 2010, p. 325). In this regard, it is important to re-visit the practice in the local government, as the local government is the most dynamic, innovative, and diverse level of the government (Cox et al., 2010, p. 325).

To get the holistic picture of JPSM research focus, we invoke the "Practices for Effective Local Government Management", developed by members of the International City/County Management Association (ICMA) in 1991, the practices include:

(1) Staff effectiveness;

(2) Policy facilitation;

(3) Functional and operational expertise and planning;

(4) Citizen service; 
(5) Performance measurement/management and quality assurance;

(6) Initiative, risk taking, vision, creativity, and motivation;

(7) Technological literacy;

(8) Democratic advocacy and citizen participation;

(9) Diversity;

(10) Budgeting;

(11) Financial analysis;

(12) Human resource management;

(13) Strategic planning;

(14) Advocacy and interpersonal communication;

(15) Presentation skills;

(16) Integrity;

(17) Personal development ("Practices for Effective Local Government Management", 1991).

For most of the last two decades, these practices were accepted as relevant for education of future city managers (Cox et al., 2010, p. 329; Wessels, 2005, p. 1508). They can therefore, serve as research focus areas for researchers in the local government (Streib, Slotkin, \& Rivera, 2001, p. 515). The comparison of the ICMA core focus areas with the unit standard categories and the research focus of researchers in the JPSM is shown in Table 3 below.

Table 3

Comparison of ICMA Focus Areas With Unit Standard Categories (USC) and the Research Focus Areas of the JPSM

\begin{tabular}{lll}
\hline ICMA focus areas & Unit standard categories & Research focus \\
\hline Staff effectiveness & Human Resource Management (HRM) & 4 \\
Policy facilitation & Policy Analysis and Management (POL) & 0 \\
Service delivery management & Managing Public Service Delivery (PSD) & 15 \\
Strategic leadership & Public Organizational Development and Management (ODM) & 3 \\
Democratic responsiveness & - & 0 \\
Organizational planning and management & Public Organizational Development and Management (ODM) & 3 \\
Communication & Information, Knowledge, Communication and Technology & 1 \\
Integrity & Management (ICT) & 1 \\
\hline
\end{tabular}

Note. Source: Adopted from Wessels (2005, p. 1508) and JPSM (2011-2016).

The findings above indicate that the five focus areas covered by the Journal of Public Sector Management also reflect the ICMA focus areas, except it was not possible to find the comparison for the ICMA focus area "democratic responsiveness". Similarly, the ICMA focus areas did not cover the following unit standard categories: "Development Management" (DEV), "Financial Management and Procurement" (FMP), "Public Administration and Management History, Theory and Research" (HTR), "Disaster Studies" (DIS), and "Inter-Governmental Relations" (IGR). With exception to these, there is a positive correlation between the articles published in the Journal of Public Sector Management from 2011 to 2016 and ICMA focus areas. The findings collaborate what Wessels (2005, p. 1508) reported in South Africa. 


\section{Discussions}

From triangulation of the findings obtained from categorization of unit standards for public administration and issues reported in the JPSM from 2011 to 2016 in Table 2, and comparison of the ICMA focus areas, unit standard categories, and the research focus areas in the JPSM from 2011 to 2016 using the analytic variable of the research topic, we can make following analysis.

The analysis of all topics researched in the JPSM from 2011 to 2016 revealed that there is heavy slant towards practice $(96.62 \%)$ at the expense of the theory in the journal. These tally with what Marijani (2017) reported in his analysis that $72.5 \%$ of the articles were found to be practice-oriented in a study that comprised of 80 articles from the Journal of Policy and Leadership (JPL) and Uongozi: Journal of Management and Development from 2007-2014 in Tanzania.

A comparison of this finding with other studies in Africa reveals that practice-oriented research has dominated in both doctorates and articles, with $86 \%$ and $89 \%$ of articles in the journals and $60.4 \%$ of doctorates being practice oriented from 1994 to 2009 (Milne, 2009, p. 68; Cameron \& McLaverty, 2008; Hubbell, 1992; Wessels, 2004). This practice is associated with the students or researchers post study career in Africa (Milne, 2009, p. 68).

At an international level, the findings still support the conclusions drawn by McCurdy and Cleary (1984), White (1986), Box (1992), White and Adams (1994), Huston and Delevan (1990), Perry and Kraemer (1986), and Stallings and Ferris (1988). There are several reasons to explain this situation. First and foremost is its perennial fight over its identity, relevance, and focus (Kettl, 2000, p. 7). The second is its marginalization by practicing administrators who once relied heavily on the field's counsel. In this regard, within both the academic and practice milieu, public administration is struggling to reoccupy its former intellectual niche and redefine its foundation (Kettl, 2000, p. 7). The third is the topic and theme focus of the journal itself; since its establishment in 2011, the JPSM's focus and theme has been solely focusing on public sector management practice theme at the expense of the development of the field.

\section{Conclusions and Recommendations}

This paper has presented the locus and focus of public administration research in Tanzania, through the assessment of articles published in the Journal of Public Sector Management from 2011 to 2016. The question "what topic was studied?" was used descriptively in this paper. Generally, the findings imply that the practice is dominating the research at the expense of the theory. In sum, Schwella's (2000, p. 38) observation on the dominance of a theoretical administrative process approach is still valid to date.

To restore the former public administration intellectual predominance and its foundations, the editors and authors of JPSM should include the topics and themes that focus on the "public administration theory and research", including:

(1) Public administration research;

(2) Administrative theory;

(3) Bureaucratic theory;

(4) Organizational theory;

(5) Research methodology and public administration and management history, theory and research (HTR). 


\section{References}

Auriacombe, C. J., \& Holtzhausen, N. (2014). Theoretical and philosophical considerations in the realm of the social sciences for public administration and management emerging researchers. Administratio Publica, 22(4), 8-25.

Auriacombe, C. J., \& Mouton, J. (2007). Qualitative field research. Journal of Public Administration, 42(6), 441-457.

Box, R. C. (1992). An examination of the debate over research in public administration. Public Administration Review, 52(1), $62-69$.

Brynard, P. A. (1989). Administratiewe hervorming (Administrative reforms). In J. T. Bekker (Ed.), Politieke hervorming (Political reforms). Johannesburg: Macmillan South Africa.

Cameron, R. (2008). Public administration in South Africa: The state of the academic field. Administratio Publica, 15(2), 43-68.

Cameron, R., \& McLaverty, L. (2008). Public administration research in South Africa: An assessment of journal publications, 1994-2006. Administratio Publica, 15(2), 69-96.

Clapper, V. (2000). The SAQA challenge to public administration and management theory and practice, or how not to draw a house. In F. Theron and E. Schwella (Eds.), The state of public and development management in South Africa: The Mount Grace II papers (pp. 55-59). Stellenbosch: University of Stellenbosch.

Cleary, R. E. (1994). Revisiting the doctoral dissertation in public administration: An examination of the dissertations of 1990. In J. D. White and G. B. Adams (Eds.), Research in public administration, reflections on theory and practice (pp. 157-170). United States of America: Sage Publications.

Cox, R., Gerald, T. G., \& Levin, M. M. (2010). Educating local government managers for the twenty-first century: A preface to the symposium. Journal of Public Affairs Education, 16(3), 325-336.

Elcock, H. (2004). Public administration: Why are we in the mess we're in? Public Policy and Administration, 19(2), 3-7.

Fourie, D., \& Wayne, P. (2017). Public sector inefficiencies: Are we addressing the root causes. South African Journal of Accounting Research, 31(3), 169-180.

Greenwood, J., \& Eggins, H. (1995). Shifting sands: Teaching public administration in a climate change. Public Administration, 73(1), 143-163.

Gulick, L. H., \& Urwick, L. F. (1937). Papers on the science of administration. New York, NY: Harcourt.

Henry, N. (1975). Paradigms of public administration. Public Administration Review, 35(4), 378-386.

Houston, D. J., \& Delevan, S. M. (1990). Public administration research, an assessment of journal publications. Public Administration Review, 50(6), 674-681.

Hubbell, L. (1992). A lack of relevance: Political correctness in South African public administration. Administratio Publica, 4(1), 1-17.

Hummel, R. (1991). Stories managers tell: Why they are as valid as science. Public Administration Review, 51(1), 31-41.

ICMA. (1991). Practices for effective local government leadership. Retrieved from https://icma.org/practices-effective-localgovernment-leadership

Kettl, D. F. (2000). Public administration at the millennium: The state of the field. Journal of Public Administration Research and Theory, 10(1), 7-34.

Langos, S. (2014). Athens as an international tourism destination: An empirical investigation to the city's imagery and the role of local DMO's. MSc in Marketing Management, University of Derby.

Mabin, A. (2003) .The role of research and training in the transformation of the public service. Unpublished paper, Johannesburg.

Marijani, R. (2017). Public administration research in Tanzania: An assessment of journal publications, 2007-2014. Asian Journal of Humanities and Social Studies, 5(2), 80-92.

McCurdy, H. E., \& Cleary, R. E. (1984). Why can't we resolve the research issues in public administration? Public Administration Review, 44(1), 49-55.

Milne, K. C. (2009). A critical analysis of public administration doctorates in South Africa, 1994-2007. MSc in Public Administration and Administration, University of Cape Town.

Ospina, M. S., \& Dodge, J. (2005). It's about time: Catching method up to meaning-The usefulness of narrative inquiry public administration research. Public Administration Review, 65(2), 143-155.

Perry, J. L., \& Kraemer, L. K. (1986). Research methodology in the public administration review, 1975-1984. Public Administration Review, 46(3), 215-226.

Rekdal, O. (2014). Academic urban legends. Social Studies of Science, 44(4), 638-654.

Sanina, A., Balashov, A., \& Kaysarova, V. (2016). Public administration research in contemporary Russia: An analysis of journal publications, 2010-2014. International Journal of Public Administration, 40(12), 1-14. 
Schwella, E. (2000). Paradigms: Context and competencies. In F. Theron and E. Schwella (Eds.), The state of public and development management in South Africa. The Mount Grace II papers (pp. 33-43). Stellenbosch: University of Stellenbosch.

Stallings, R. A., \& Ferris, J. A. (1988). Public administration research: Work in public administration review 1940-1984. Public Administration Review, 48(1), 580-587.

Standard Generating Body. (2005). Standard generating body for public administration and management. Retrieved from http//www.jupmet.org.za/titles.htm

Streib, G., Slotkin, B. J., \& Rivera, M. (2001). Public administration research from a practitioner perspective. Public Administration Review, 61(5), 515-523.

Taylor, F. W. (1911). Principles of scientific management. New York: Harper and Brothers.

Thornhill, C. (2008). Research in public administration: Some South African development. Administratio Publica, 15(2), 1-18.

Unal, M., Metin, T., \& Veysel, B. (2012). Ethical violations and sanctions in scientific publications: A framework proposal for social sciences and humanities. TODAIE's Review of Public Administration, 6(3), 1-31.

Van der Waldt, G. (2013). Towards a typology of models in public administration and management as the field of scientific inquiry. African Journal of Public Affairs, 6(2), 38-56.

Wessels, J. S. (2004) Public administration research: A South African masquerade. Journal of Public Administration, 39(1), 168-183.

Wessels, J. S. (2005). The challenges of knowledge production by researchers in public administration, a South African perspective. South African Journal of Higher Education, Special Issue, 1499-1515.

Wessels, J. S. (2008). South African trends in masters and doctoral research in public administration. Administratio Publica, 15(2), 97-120.

White, J. D. (1986). Dissertation and public administration. Public Administration Review, 46(3), 227-234.

White, J. D., \& Adams, G. B. (1994). Making sense with diversity: The context of research, theory and knowledge development in public administration. In J. D. White and G. B. Adams (Eds.), Research in public administration, reflections on theory and practice (pp. 1-24). United States of America: Sage Publications.

White, L. D. (1926). Introduction to the study of public administration. New York City: The Macmillan Company.

Wilson, W. (1887). The study of administration. Political Science Quarterly, 2(2), 197-222.

Wu, X., He, Y.-L., \& Sun, M. T.-W. (2013). Public administration research in mainland China and Taiwan: An assessment of journal publications, 1998-2008. Public Administration, 91(2), 261-280. 